\title{
Reflection on Business English Teaching and its Future Trend
}

\author{
Yanling Tang \\ School of Foreign Languages, Changchun Institute of Technology, Jilin 130012, China \\ tangyanling_bird@yahoo.com
}

Keywords: Business teaching; reflection; ability; social requirements.

\begin{abstract}
With the development of international trade, business talents are badly needed by those international trade, especially those who are not only a bilingual speakers, but also with business skills and experience. This arises more requirements for business teachers, not only they need business background, but also they can take update teaching techniques which can offer their students profound knowledge in this field. This paper tries to study the job markets of business and to find out their requirements to the graduates in business major, and it puts forward some teaching suggestions after reflecting the old teaching system and methods. The purpose is to elevate the ability of the students and adapt themselves to its future development.
\end{abstract}

\section{Introduction}

According to statistics, there are approximately 500 colleges and universities have opened Business English major, and for many years they consistently contributed the massive talented people for the international exchange and cooperation of our foreign trade and economic developments, this is a notable and significant development in reconstructing course offering system and improving students' comprehensive qualities [1]. While according to information available and the practical work those business English graduates are doing, it is obviously seen that under such big data age, what the students are learning is really limited, especially from the high-tech point of view. Therefore, aiming at the solving these problems this paper put forward that teachers in business courses should reflect their curriculum design and some new concepts should be introduced into the whole the teaching system to help the students convert their knowledge into practical abilities, such as interpersonal skills, negotiation, presentation and so on.

\section{Investigation and Survey of Business English Training Programs in some universities}

1) Investigation done on the Internet

There are approximately 800 colleges and universities set up Business English course and 167 colleges and universities set Business English course at the graduate school level in China. Through investigation, 30 colleges and universities are chosen including Guangdong University of Foreign Studies and University of International Business and Economics etc through Internet and field research, the firsthand information is got about the actual situation of Business English major training program. And the list of these 30 colleges and universities are shown on Fig. 1.

Comments: training program refers to a full set of practice concerning train business translation, negotiation and presentation abilities; and presentation practice refers to practice aims at training communication, investigation and presentation abilities.

From the chart we can see among all the 30 universities and colleges investigated there are 28 universities have opened business English course, and only 5 of the 30 schools have set a full set of training program, and approximately $70 \%(22$ in 30) of the schools have opened translation related courses and practice, while seldom have negotiation practice and presentation practice opened in the investigated schools. However, negotiation and presentation practice are quite important in converting knowledge learned in classes into practical ability, let alone what a well-designed and systematic training program could bring to a students. 
Therefore, we can infer from this investigation that a well-designed and systematic training program which combines translation, negotiation and presentation practice in one and aiming at drilling students' ability of converting international trade knowledge into practical ability is a considerable and flexible solution to the urgent needs of employing units, graduating students and colleges and universities[2].

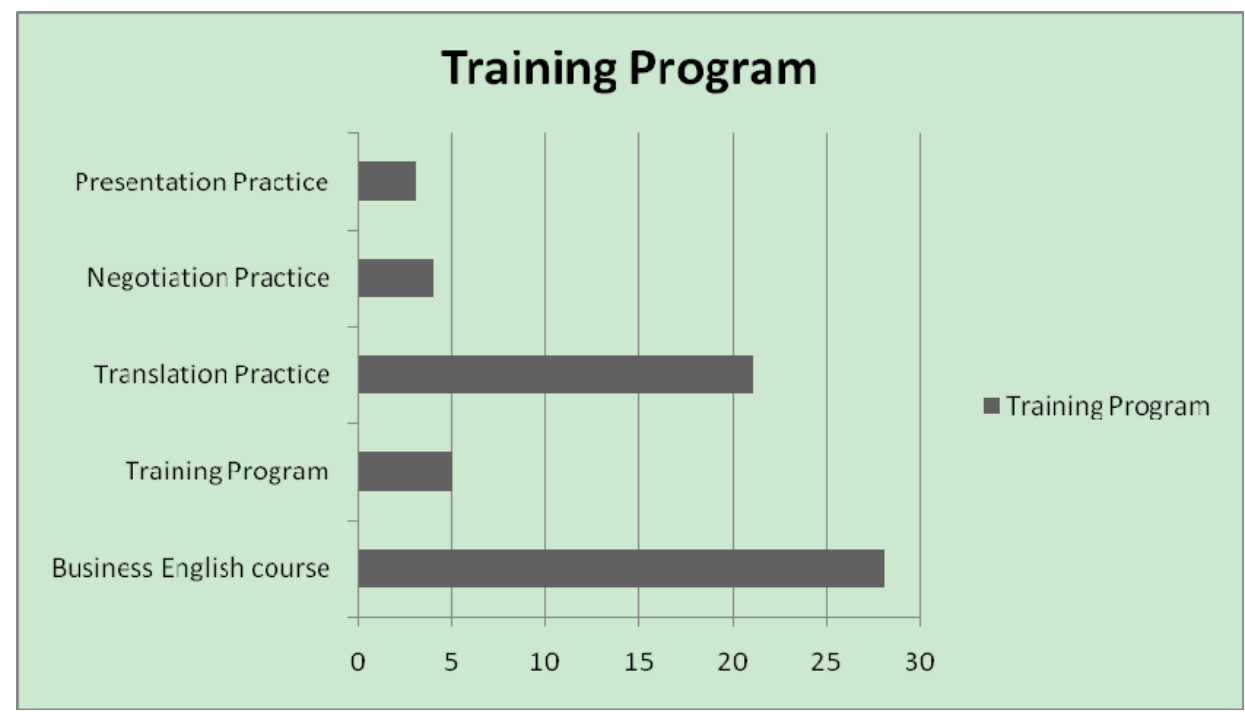

Fig. 1 Contents of training program

\section{2) Field Research}

The field research involves two universities: Guangdong University of Foreign Studies and South China Normal University. The result of this field research is as follows:

\subsection{Guangdong University of Foreign Studies}

Under the institute of international business management, business English, international economic law and international business of the four professional direction, and main focus is on the business English line. Here is their course design:

Professional required courses include Comprehensive English, English Writing, Advanced English, Business Communication, English Interpretation, Business Interpretation, English Translation, Brief Introduction of Contemporary Business( English), Principles of Management( English), Enterprise Strategic Management( English) and Oral English; Practical Teaching includes course practice and professional practice for 8weeks

The unique feature of business English major is their course practice: Business English Presentation Contest. It is a full set of training program involving the following steps: one class was divided into several groups and about ten to fifteen students form a group, each group choose a actual brand name such as Haagen-Dazs, IKEA and China Southern Airlines, under the direction of an efficient group leader, several students in charge of a subtask, such as contacting the subsidiary company of the brand they chose in Guangzhou and get the first hand information that they might not obtain from the internet, and in this process required the ability of communication and gain confidence from strangers, while some group members search information they need on the internet; then the second step is design questionnaire in order to get to know about the problems and deficiencies might exist in the operating management under the brand, for the sake in the presentation contest they would offer some flexible proposal to those problems, while in this process involved the ability of converting knowledge into practical ability since they have to combine the information they have collected in the first phase of the practice and focusing on strength and weakness of the brand name and design the questionnaire on their own; then the third step is to do the SWOT analysis and in this process involving analyzing the questionnaire and do the SWOT analysis: the final step is the presentation contest, group members are required to present the result they have investigated in fluent English and design the PPT to convince the judges. 
From the whole process we can see students utilize knowledge they learned from class and convert into practical ability [3], which is a good example we can emulate in the design of business English training program.

\subsection{South China Normal University}

In the English major of school of foreign studies, there are three directions: teacher-training, translation and business English, and focus is on the business English direction. Here is their international commercial module which is required to finish before graduation:

International commercial module includes Brief Introduction of Contemporary Business, International Commercial Law, Business English Oral English, Business Negotiation, Business English Writing, International Enterprise Management, International Marketing, Business Correspondent and Practice of International Trade.

According to a junior student of international commercial direction, they have a business negotiation contest in second term of their junior year. Normally, 4 students form a team, while under the specific negotiation topic given by the organizing committee, cases in the topic by taking the form of actual company, according to the negotiation plan each team submit and actual negotiation process proceed under the specific judges would give credits according to their performance. In the process of writing negotiation plan, students have to utilize the relevant negotiation knowledge and collect information about their company and their rival's as well. And certain skills are required to perform such as presentation and negotiation in the process of actual negotiation. Therefore, we could emulate their merit in designing the business English training program.

\section{Reflection on the teaching method and course design}

Referring to the information collected during field research, a suggestion for business courses design can be given as follows.

The whole training program can be divided into 4 modules: Business Etiquette Training, Business Presentation Contest, International Trade Practice and Business Negotiation Contest.

People depend on certain established protocol to retrain their every aspect in their business activity in order to assert a mutual respect. Since graduating students seldom have the chance to participate in real business activity, a good business manner would leave a good impression on their interviewer and clients when they are haunting for jobs and receiving clients respectively. While the art of communication is quite important when they are making efforts to develop clients and maintain the relationship. And a good understanding of cultural difference would avoid unnecessary misunderstanding and offensiveness when they are receiving foreign clients [4]. And the knowledge students received in this module will be utilized in the following modules.

Since this training program is designed in an organized and systematic way, and each module has a specific training target, different majors such as business English, international trade, marketing and so on could adopt any one of these four modules or the whole training program according to actual needs; and the duration and form of each module can also be designed according to colleges and universities' course design and time schedule.

\section{Summary}

Through analysis the domestic business English major situation and employment situation of business English graduates, this paper gets that there is a gap between the expectation of employing units and business English graduates' real abilities when they start work, and the author aims at solving this problem by promoting business English training program under the direction of needs analysis theory. Under the big data age, multimedia is an effective way to enhance the teaching of business courses, while at the same time it can be used to train some unemployment in the society.

Though this paper investigates colleges and universities and job fair which have a direct relation with business English graduates' employments, due to lack of experience, the author may have not included all the aspects of business English employing units' needs, and this paper has trouble in 
getting accurate and detained information about training program in colleges and universities which merits investigation and analysis. And some negative effects may bring in by missing those advantages of training programs in the paper. The author hopes that a further investigation can be conducted ti make up for these limitations.

\section{Acknowledgements}

The author would like to give her thanks to Jilin Social Science Foundation (NO.2014wy23) and Changchun Institute of Technology for their financial and technical support.

\section{References}

[1]. Brindley, Gz The role of needs of analysis in adult ESL program design in Johnson, R.K(ed). The second language curriculum. Cambridge: Cambridge University Press, 1989

[2]. Zeng Zhaotao, Zeng fanfen, Practical teaching research in business English majos. Panyu Technical Institution, 2005

[3]. Edward J.Deak. E-Commerce and Network Economics.Northeastern Finance University, 2006, p 50-52.

[4]. Gary P.Schneider.E-Commerce (English Version). Mechanics Industry Press, 2006, p 27-29. 